\title{
The Effectiveness of Online Learning Methods During the Covid-19 Pandemic
}

\author{
Iskandar Muda Purwaamijaya*, Rina Marina Masri \\ Civil Engineering Department \\ Faculty of Technology and Vocational Education \\ Universitas Pendidikan Indonesia \\ Bandung, Indonesia \\ *ais_imp@upi.edu, rinamasri@upi.edu
}

\author{
Btari Mariska Purwaamijaya \\ Digital Business Study Program Tasikmalaya Campus \\ Universitas Pendidikan Indonesia \\ Tasikmalaya, Indonesia \\ btarimariska@upi.edu
}

\begin{abstract}
The education environment in Indonesia has actually been implementing online distance learning methods for a long time, especially at universities. Several universities in Indonesia have started implementing the hybrid learning method for their students, which combines face-to-face lectures in classrooms with online learning through application provided by the University. However, in the conditions of the Covid-19 pandemic, the whole learning method changed to an online learning method, which in its implementation, the use of online learning faced many challenges. Research is needed with a comprehensive qualitative approach, and exploration to find out the effectiveness of the implementation of online lectures through the platforms provided by the University and other platforms during the Covid-19 Pandemic. The results of the study are useful for improving and aiming at evaluating the strategy that has been implemented previously based on the results of research related to the effectiveness of online learning methods during the covid-19 pandemic that needs to be anticipated by universities to become a center of excellence.
\end{abstract}

Keywords-Covid-19 pandemic, online learning, students, education

\section{INTRODUCTION}

In December 2019, there were several new cases of mysterious pneumonia in Wuhan, Hunbei Province, China. This disease is caused by the Severe Acute Respiratory Syndrome Coronavirus-2 (SARS-CoV-2) virus that is carried by animals. The disease has been temporarily named the 2019 novel coronavirus (2019-nCoV). Then 11 February 2020, WHO announced the name of this disease, namely the 2019 coronavirus disease (COVID-19). Transmission of SARSCoV-2 from symptomatic patients occurs through droplets emitted when coughing or sneezing. So on March 11, 2020 WHO characterized COVID-19 as a global pandemic [1]. WHO confirmed that on May 3, 2020 the Covid-19 pandemic caused a total of 3,272,202 positive people, 230,104 deaths and 91,977 healed worldwide. Whereas in Indonesia it was announced that the first positive case occurred on March 2, 2020 with two patients. The Task Force for the Acceleration of
Handling Covid-19 confirmed that on May 3, 2020 there were 10,843 positive people, 831 fatalities, and 1,665 recovered [2].

These unpredictable conditions created urgent changes in various sectors, which had an impact on policies to be implemented. One of them occurs in education at the University, to change learning method. For some universities, hybrid learning method is usually carried out, which is a combination of face-to-face learning in classrooms and online learning, now it must be fully implemented by online-based distance learning, in accordance with government recommendations [3]. Although in several studies, the integration of educational methods through online learning has benefits and can improve learning outcomes for students, this alternative also raises various challenges related to internet coverage, the availability of computers or smartphones in the community [4,5]. In its contribution to education, the University as a Center of Excellence, apart from providing various platforms, also needs to carry out analysis and improvements, both in terms of policies and online learning systems so that they can take alternatives quickly as a form of response to the situation amid the Covid-19 pandemic and increase effectiveness and the quality of online lectures.

\section{LITERATURE REVIEW}

\section{A. Blended Compared with Online Learning}

The rapid development of technology continues to make the education system better and more advanced, from using only conventional systems to switching to fully digital systems resulting in online learning, as a way of teaching and learning using electronic media and using the internet as an intermediary in the teaching and learning process. In its implementation, it turns out that online learning is not enough because there are still various obstacles, because there is no interaction in the learning process. Meanwhile, the teaching and learning process certainly requires a system that can carry out a two-way process. Feedback is certainly needed so that learning outcomes are better. Although a lot of material is 
obtained using E-Learning, the learning process that can be done anywhere and anytime is still less effective and efficient.

So that the Blended Learning method appears, as a way of the teaching and learning process that combines and blends conventional education systems with systems that are all digital. Blended Learning can reduce education costs and improve learning outcomes. So that the learning process does not only take place in the classroom but also takes advantage of the virtual world [6].

\section{B. Student Perception of Online Learning}

Based on the results of previous studies that have regarding students' perceptions of the implementation of online learning, it is running poorly due to the internet network which is sometimes slow and disconnected and the limitations of students who do not understand information communication technology and do not understand the procedures in implementing online-based learning, so there is a need for good cooperation both between the principal, teaching staff, students and technology managers so that the implementation of online learning can run optimally so it can improve student learning achievement and also regular evaluation is required [7].

\section{Delivery Platform of Online Learning}

Educational technology recognizes at least two types of learning online, namely synchronous learning and asynchronous learning. Synchronous learning is considered of higher quality than asynchronous learning because synchronous learning is regular face-to-face learning online or in real-time networks. Meanwhile, asynchronous learning is online learning that does not require an intense teachinglearning interaction between teaching staff and students. The teaching staff can put materials, assignments, and evaluations in a predetermined place and let students try to find them independently and not real-time [8].

Several platform options are available for online learning exclusive web-based environments or email or mobile. At this time, the delivery of content in the online learning process involves a Learning Management System (LMS). LMS acts as a platform in creating learning interactions where learning activities are managed through a virtual classroom. The use of virtual classes with LMS has advantages in terms of the availability of menus and features that students can use to study teaching materials, activities, and measure their understanding of learning materials like conventional learning [6,9].

\section{METHODS}

This research was conducted with a comprehensive qualitative approach, and exploration [9]. Research based on secondary data from previous studies by exploring various articles, papers from company research and other literature. The study conducted a primary data collection from around 90 respondents among students in various educational backgrounds in Indonesia in order to find out about of The Effectiveness Of Online Learning Methods During The Covid-
19 Pandemic, which contains the substance, among others, are as follows (1) information regarding the Study Program environment; (2) information about the Faculty / Campus environment; (3) where the respondent lived during the Covid19 Pandemic; (4) forms of organizing online learning at the University; (5) the media used for the online learning process; (6) whether online learning runs according to the schedule set by the university; (7) the process of adapting the online learning system; (8) how effective is the information or material obtained from online learning; (9) has the online learning system facilitated the lecture process; (10) barriers experienced during online learning; (11) responses to online learning systems during the Covid-19 pandemic; (12) responses to the media used for the online learning process.

\section{RESULTS AND DISCUSSIONS}

\section{A. Respondent Profile}

Respondents in this study were students at UPI. The number of respondents was 90 , with the average age being 15 19 years old. The places where respondents lived during the Covid-19 pandemic are as follows.
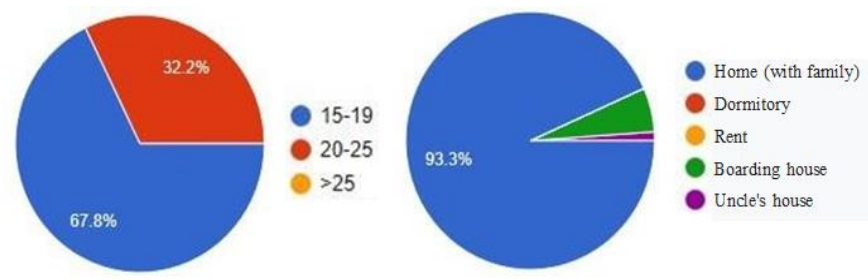

Fig. 1. Figure 1 and 2 respondent profile.

Based on this picture, it can be seen that the number of students who filled out the questionnaire aged 15-19 years old and lived with their family during the Covid-19 pandemic.

\section{B. Online Learning Methods during the Covid-19 Pandemic}

Regarding the online learning methods discussed during the Covid-19 Pandemic period, it consists of several substances, including the implementation of learning, the media used for online learning, the implementation schedule, the effectiveness of online learning methods during the pandemic and the influence of the online learning system on the ease of student lectures. during a pandemic. The complete data can be seen in the image below.

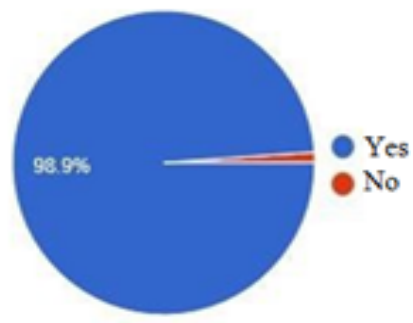

Fig. 2. Students implement online learning 


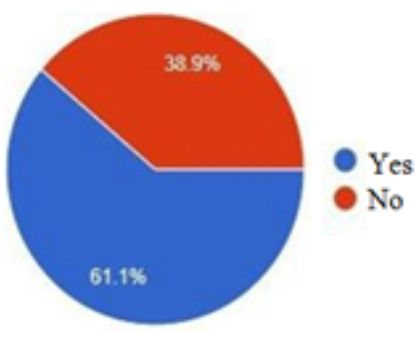

Fig. 3. Lectures teach according to the specified time.

Based on the picture above, it is known that the respondents answered various questions. Figures 2 and 3 explain that as many as $98.9 \%$ of students do online learning and $61.1 \%$ state that the implementation schedule has been running according to the specified time. Based on the findings, to ensure appropriate staff discipline there is need for a enabling teaching environment to be created. Lecturers should be properly rewarded fortheir effort through improve conditions of serves. In-service training for all lecturers should be made compulsory to enhance their job satisfaction [10]. However, the situation during the Covid-19 Pandemic was not entirely ideal and had a major impact on the conditions of online learning. Students and lecturers need time to adjust lecture schedules. This schedule adjustment is also carried out with many considerations, including considering the conditions of lecturers and students at home.

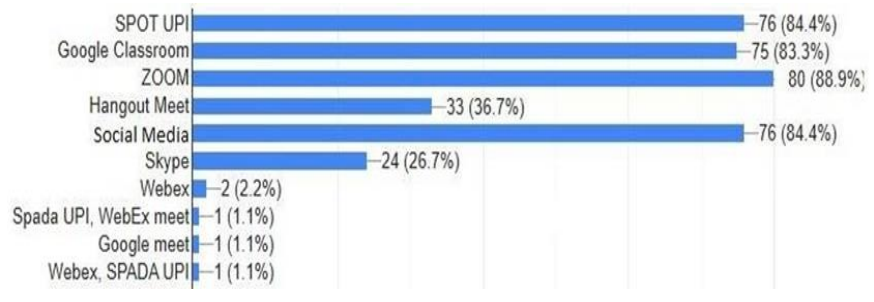

Fig. 4. Media used in the online learning process.

Figure 4 (the media used in online learning) shows that the ZOOM platform is the most widely used $(88.9 \%)$, followed by SPOT UPI, social media (84.4\%), and Google Classroom $(83.3 \%)$. Based on this, it can be seen that the majority of online learning uses six media. In one course, several media can be used to deliver material.

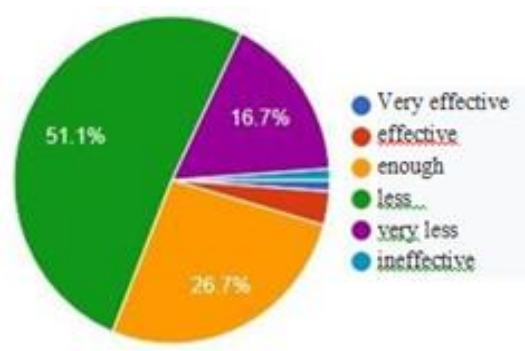

Fig. 5. Effectiveness of online learning.

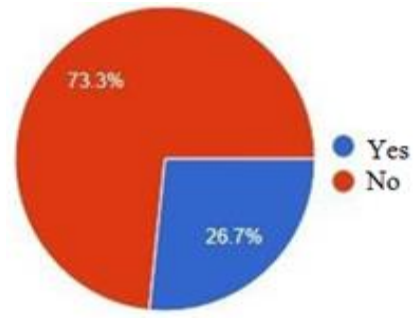

Fig. 6. Simplify learning.

University support in providing facilities and infrastructure is very much needed, because seen from the university platform data, SPOT UPI is still less attractive than the ZOOM MEETING application. Universities must be able to contribute to a smooth and comfortable online learning system to be effective in its implementation. Of course, there are still many things that must be addressed by universities in creating their own platforms. For some respondents, the online learning system could facilitate the learning process during the Covid19 pandemic, however $(73.3 \%)$ stated that the online learning system did not facilitate the learning process. In addition, in Figure 5 it can be seen that $(51.1 \%)$ students stated that online learning methods were still less effective.

\section{Learning Barriers and Solutions}

The Online Learning Method during the Covid-19 pandemic as one of the best solutions in carrying out the learning process, still faces many problems that become obstacles for students and lecturers. The respondents' responses are as follows.

\section{What was your response to the online leaming system during the Covid-19 pandemic? 90 responses \\ Less effective, considering that more lecturers only give assignments without giving. explanations and students are quite difficult to also find material. \\ This online leaming system in my opinion is very ineffective because there are many lecturers who choose to give assignments without material, and the limited signal that is sometimes bad and difficult to use in this online learning meda, as well as irregular course schedules:) \\ Less effective}

Fig. 7. Learning barriers and solution.

From Figure 7, it can be seen that there are many problems that become obstacles for students and lecturers. This must be addressed properly by all parties, including the students themselves. The role of the University as a center of excellence must be able to improve and facilitate the achievement of an effective online learning system by participating in improving the quality of teaching staff when working from home.

\section{CONCLUSIONS}

Based on research, the online learning method does make learning easier, because with this method, students can communicate directly with their lecturers, even questions that 
have not been discussed in lectures can be asked in various conditions using the platform. However, the effectiveness of online learning methods during the Covid-19 pandemic was greatly influenced by various challenges that needed to be resolved between collaboration from government policies and universities as facilitators and the Center of Excellence for online learning methods, so that students could continue to study well in difficult situations like this. The online learning method is expected to facilitate learning so that the material presented can be easily understood during the Covid-19 pandemic through improving the quality of the online learning platform and increasing the capacity and discipline of lecturers as their commitment as teaching staff.

\section{REFERENCES}

[1] WHO. WHO Timeline - Covid-19. Accessed May 3rd, from https://www.who.int/news-room/detail/27-04-2020-who-timeline--covid-19, 2020.

[2] WHO. Coronavirus disease (COVID-19) outbreak situation, Accessed May 3rd, from https://covid19.who.int/, 2020.

[3] D. Khasanah, H. Pramudibyanto, \& B. Widuroyekti. Pendidikan Dalam Masa Pandemi Covid-19. Jurnal Sinestesia, Vol. 10, No. 1, 2020.
[4] G. Basilaia, D. Kvavadze. Transition to Online Education in Schools during a SARS- CoV-2 Coronavirus (COVID-19) Pandemic in Georgia, 2020.

[5] M. Aghajani, M. Adloo. The Effect of Online Cooperative Learning on Students' Writing Skills and Attitudes through Telegram Application. International Journal of Instruction, 2018.

[6] B. Means, Y. Toyama, R. Murphy, M. Bakia, K. Jones, Center for Technology in Learning. Evaluation of Evidence-Based Practices in Online Learning: A Meta-Analysis and Review of Online Learning Studies, pp. 37-48, September 2010.

[7] C. M. Holmes, C. Reid. A Comparison Study of On-campus and Online Learning Outcomes for a Research Methods Course. The Journal of Counselor Preparation and Supervision, Volume 9 Number 2, 2017.

[8] S. Vonderwell, X. Liang, K. Alderman. Asynchronous Discussions and Assessment in Online Learning. JoURNAL of RESEARCh oN TEChNoLoGy IN EDUCATIoN, 39(3), pp. 309-328, 2007.

[9] N. A. Adzharuddin, and L. Hwei Ling. Learning Management System (LMS) among University Students: Does It Work? International Journal of e-Education, e-Business, e-Management and e-Learning, Vol. 3, No. 3, pp. 248-252, June 2013

[10] V. O. Ebuara1 , M. A. Coker. Influence of Staff Discipline and Attitude to Work On Job Satisfaction Lecturers in Tertiary Institutions in Cross River State. Public Policy and Administration Research www.iiste.org ISSN 2224-5731(Paper) ISSN 2225-0972(Online) Vol.2, No.3, 2012. 